\title{
Experimental Investigation on the Mechanical Behavior of Semi-Rigid Composite Joints Loaded along the Minor-Axis
}

\author{
Shizhe Chen ${ }^{1,2}$, Zhan Wang ${ }^{1,2 *}$, Chao Zhou $^{2}$ and Panyuan Chen ${ }^{2}$ \\ ${ }^{1}$ State Key Laboratory of Subtropical Building Science, South China University of Technology, Guangzhou 510640, \\ China \\ ${ }^{2}$ School of Civil Engineering and Transportation, South China University of Technology, Guangzhou 510640, China
}

\begin{abstract}
Today's design of spatial steel frames requires beam-to-column connections to be checked in the direction of the minor-axis of inertia of beam section. The mechanical behavior of minor-axis connections for bare steel joints and composite joints has been investigated by experiments. A comparison of the experimental results between the bare steel joints and composite joints shows that the mechanical behavior of the minor-axis composite joint is obviously effected by the reinforcing concrete slab, which is transversely reinforced for bending and is connected to the steel beam via shear studs, this is more in line with the mechanical behavior of the frame joint. The investigation indicates that: (1) Minor-axis joints with flush end-plate connections and seat angle with double web angles connections are all typical semi-rigid joints. The bearing capacity and the rotation ability of the joints cannot be ignored in the design. (2) Due to the composite effects of the reinforcing concrete slab, sagging moment and hogging moment must be taken into consideration when the mechanical model is established using component method.
\end{abstract}

Keywords: Minor-axis, Bare steel joints, Reinforcing concrete slab, Composite joints, Experimental investigation, Mechanical property.

\section{INTRODUCTION}

In the early days, columns were usually designed with rectangular section. The $\mathrm{H}$-section columns were rarely used because this kind of section leads to a lack of lateral stiffness in the plane containing the minor-axis. Recently, with more and more supporting members being used in the structural system, the $\mathrm{H}$-section steel columns are largely applied since the problem of weaker lateral stiffness has been solved. In the design of spatial steel frames, beam-to-column joints must be considered as semi-rigid which means that they have the capacity of bending and rotation. However, these joints are idealized as rigid or pinned in traditional design.

Experimental investigation of semi-rigid joints has been started in the 70s. Simoes da Silva [1] made a very valuable work on summarizing the experiment research from 1990 to 2001.The behavior of the semi-rigid composite joints could be summarized as follows: When symmetrical loads were

*Address correspondence to this author at the State Key Laboratory of Subtropical Architecture Science, Department of Civil Engineering and Transportation, South China University of Technology, Guangzhou 510640; Tel: (+86)13825045880; Fax: +86-020-87113421;

E-mail: wangzhan@scut.edu.cn applied on the composite beams and steel columns, the value of initial stiffness and bending strength would reduce, because the steel column web in shear had a significant effect on the shear deformation of the joint panel zone. The value of initial stiffness and bending strength would increase when the beam and column were designed as composite, and the ductility did not change obviously, because the column web panel had been reinforced by the concrete. Beatriz [2,3] carried out an experimental study for evaluating mechanical performance of semi-rigid composite joints which were designed by an innovative approach and also simulated by using finite element method. The cantilevered slab was traditional designed on the back of the column for anchoring the reinforcement sufficiently. Because of this efficient design, this kind of slab could be omitted. A mechanical model for semi-rigid beam-to-column connections subjected to lateral bending (i.e., in the plane containing the minoraxis) was developed by Lima [4] within the design approach based on the component method. According to Luciano [5], the distribution of stress and strain inside the panel zone of column web was tested by an experimental study using the reflection photoelasticity techniques. The mechanical behavior and capacity of the minor-axis connections were first determined with the technology. 
Minor-axis connections are often assumed to be flexible in usual design, in which the behavior of the most structural joints could not exhibit such idealized behavior. The application of component method could help evaluating the behavior of semi-rigid joints, according to Eurocode $[6,7]$. The behavior of minor-axis joints is different from which of the major-axis joints between I-section [4], but theoretical models and experimental tests are still scanty. It is expected that the study and analysis on mechanical behavior of both minor-axis bare steel joint and composite joint should be more promoted and the contribution of concrete slab should be illustrated clearly.

Thus, two sets of tests on minor-axis semi-rigid joints are presented in this paper, each comprising two specimens with different joints, the former set without concrete slab, and the latter including a concrete slab. Under the condition that static load applied on the beam end, this paper compared the mechanical behavior differences between minor-axis bare steel joint and composite joint, the stress distribution, the plastic development, the deformation characteristic and the failure mode of the minor-axis bare steel joints and composite joints were determined and the effects of the reinforcing concrete slab on the mechanical properties of minor-axis composite joint were discussed.

\section{EXPERIMENTAL DESCRIPTION}

This experimental testing program in minor-axis joints was performed at the Structure Lab of South China University of Technology. Four prototypes, subjected to static load, were included in the program. The minor-axis connections designed in common steel frame were reproduced by the prototypes. The material properties, the geometric definition and the testing procedure were described for each model.

\subsection{Structure Model}

Four specimens with different configurations of interior joints are employed. The steel columns and the steel beams are the same for all specimens. The details of the first two specimens (TS1, TS2), so-called bare steel joints, are shown in Fig. (1), and the last two specimens (TS3, TS4) corresponding to composite joints are illustrated in Fig. (2). TS1 has two rows of bolts and two bolt-rows with flush endplate connection, and the thickness of the endplate is $16 \mathrm{~mm}$. TS2 is another typical minor-axis joint composed by double angles to the beam web and a seat angle to the column web. The bare steel parts of TS3 and TS4 are corresponding with TS1 and TS2 respectively.

In all cases of the composite joints, the reinforcing concrete slab is connected to the beam using 12 shear stubs shown in Fig. (3). The slab, 1200mm wide and $135 \mathrm{~mm}$ thick (designed in accordance with GB50010-2010 [8]), is reinforced by $9 \Phi 10$ longitudinal bars and $6 \Phi 10$ transversal bars per meter (prescribed in reference [7] for the prevention of cracking), with $25 \mathrm{~mm}$ thick concrete on the top. The details of profiled steel sheet and shear studs are illustrated in Fig. (4).

\subsection{Mechanical Properties of Materials}

The specimens are Q235 steel for both steel components and reinforcing bars (nominal yielding stress fy $=235 \mathrm{MPa}$ ), and high strength bolts of grade 10.9 are employed in this experimental program. The concrete is classified as $\mathrm{C} 25$. The compressive strength of concrete samples is $26.2 \mathrm{Mpa}$.

Main parameters of these specimens are listed in Table $\mathbf{1}$. The standard specimens are tested by the standard tensile tests and the material properties are listed in Table 2. All bolts were tightened to a pre-tension value of $155 \mathrm{kN}$ according to GB50017-2003 [9].

\subsection{Test Setup}

The main purpose of this research is to verify the initial stiffness that corresponds to the beam-column joint behavior. Four minor-axis specimens with various configurations were tested under monotonic loads, as shown in Fig. (5) and (6).

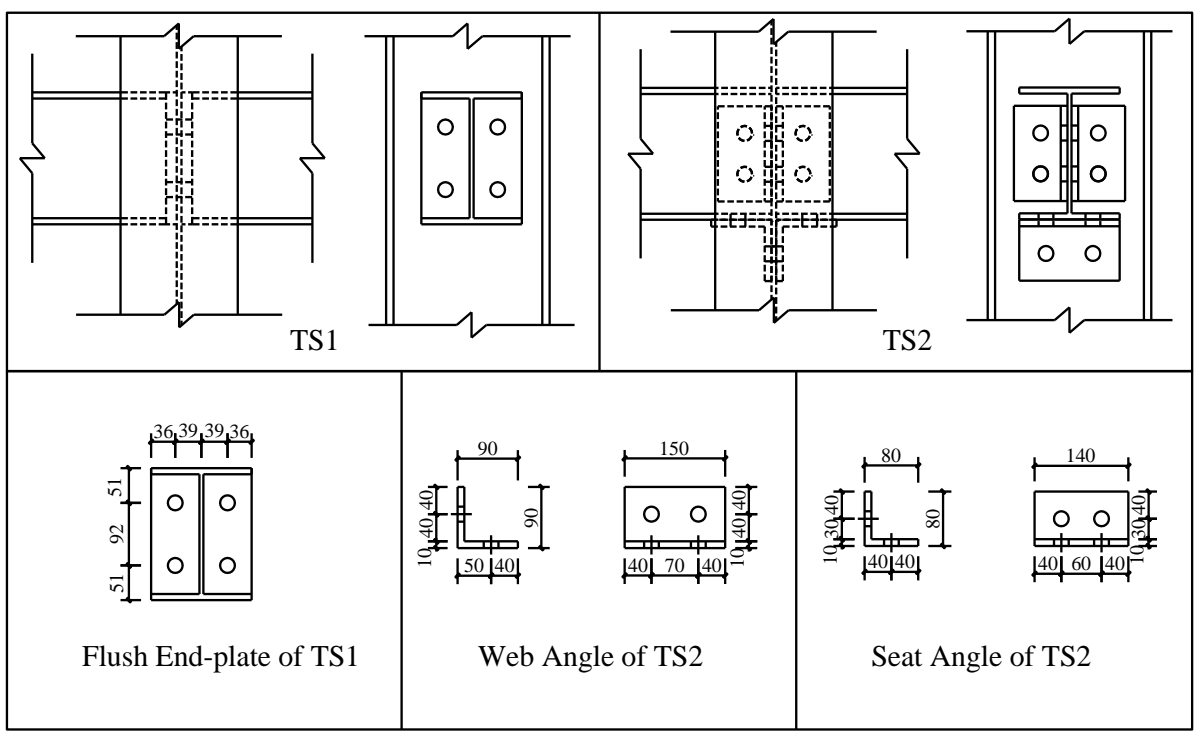

Fig. (1). Joint details of TS1 and TS2. 


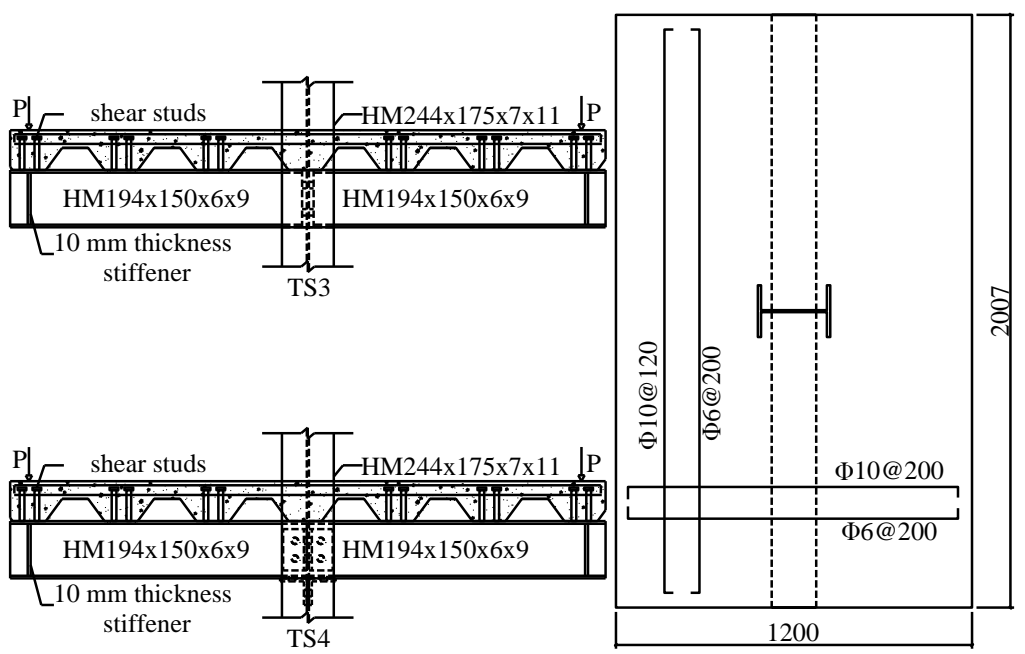

Fig. (2). Joint details of TS3 and TS4.

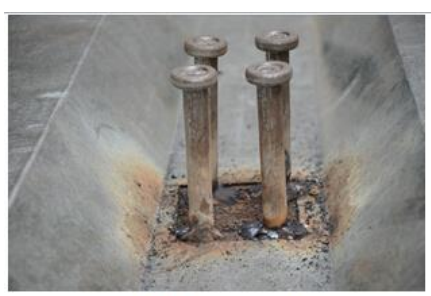

Shear studs

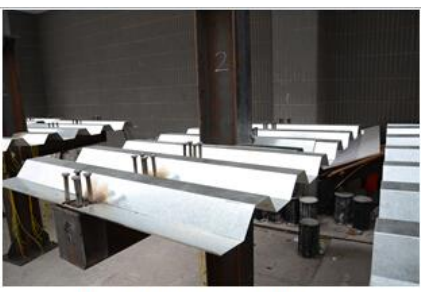

Profiled Steel Sheet

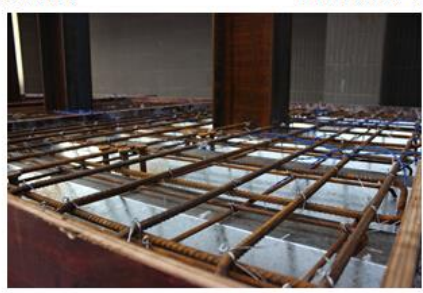

Reinforcing Bars

Fig. (3). Specimens before concreting.

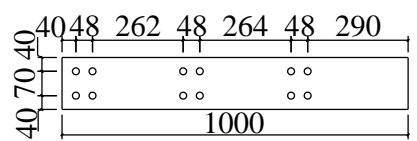

(a)Arrangement of shear studs(left beam)

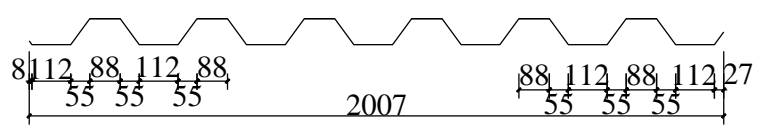

(b)Profiled steel sheet detail

Fig. (4). Arrangement of shear studs and profiled steel sheet.

Table 1. Main parameters of specimens.

\begin{tabular}{|c|c|c|c|c|c|c|c|}
\hline $\begin{array}{c}\text { Specimen } \\
\text { number }\end{array}$ & $\begin{array}{c}\text { Column profile } \\
(\mathbf{m m})\end{array}$ & $\begin{array}{c}\text { Column length } \\
(\mathbf{m m})\end{array}$ & $\begin{array}{c}\text { Beam profile } \\
(\mathbf{m m})\end{array}$ & $\begin{array}{c}\text { Beam length } \\
(\mathbf{m m})\end{array}$ & $\begin{array}{l}\text { Bolt diameter } \\
\quad(\mathbf{m m})\end{array}$ & Joint location & Remark \\
\hline $\mathrm{TS} 1$ & HM244x175x7x11 & 2000 & HM194x150x6x9 & 1000 & M20 & Interior joint & Steel \\
\hline $\mathrm{TS} 2$ & HM244x175x7x11 & 2000 & HM194x150x6x9 & 1000 & M20 & Interior joint & Steel \\
\hline TS3 & HM244x175x7x11 & 2000 & HM194x150x6x9 & 1000 & M20 & Interior joint & Composite \\
\hline
\end{tabular}


Table 2. Main material properties of the test specimens.

\begin{tabular}{|c|c|c|c|c|}
\hline Section B $\mathbf{x ~ H}\left(\mathbf{m m}^{2}\right)$ & Yield strength fy(MPa) & Ultimate strength fu $(\mathbf{M P a})$ & Elastic modulus E $(\mathbf{G P a})$ & Elongation $\boldsymbol{\Delta} \mathbf{L} / \mathbf{L}(\%)$ \\
\hline \hline $6.3 \times 10$ & 263.5 & 466.9 & 204.8 & 22 \\
\hline $8.5 \times 10$ & 262.4 & 435.3 & 196 & 22.7 \\
\hline $9.5 \times 9.9$ & 253.1 & 396.6 & 210 & 22 \\
\hline $10 \times 10.3$ & 263.1 & 445.6 & 206 & 17.2 \\
\hline
\end{tabular}

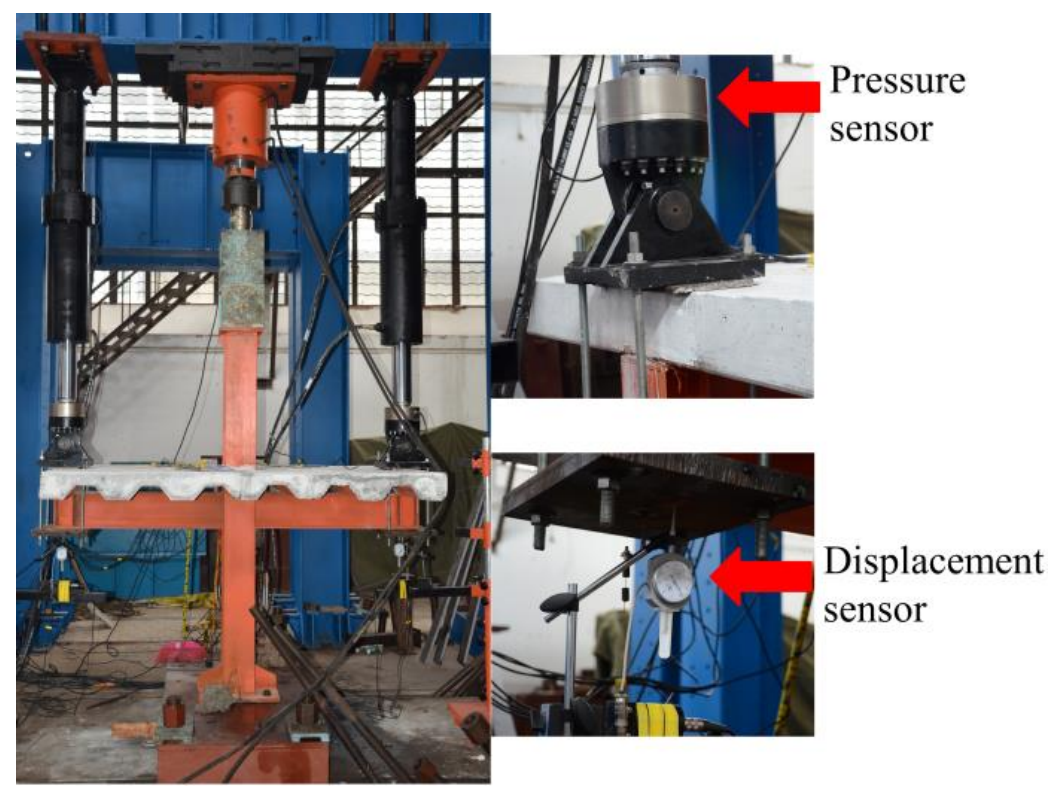

Fig. (5). Joint of interior column loaded.

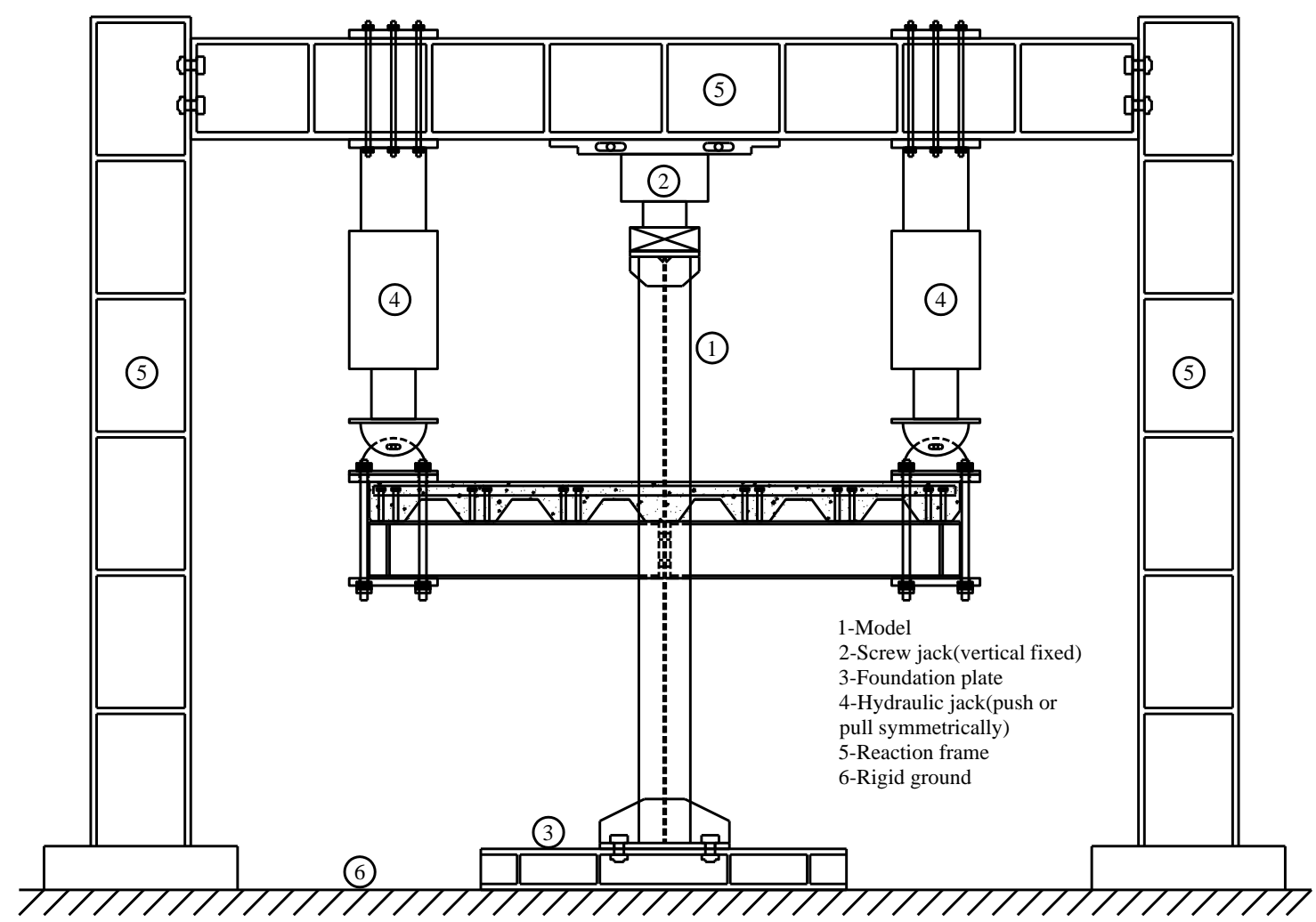

Fig. (6). Test rig. 
The top and the bottom ends of the column were fixed by the reaction frame and foundation plate, respectively. The load was applied axially on the column at a constant value of $325 \mathrm{kN}$, then concentrated force was imposed by hydraulic jacks simultaneously to each ends of the beams, as shown in Fig. (6). The maximum loading capacity of the vertical hydraulic jacks, fixed to the reaction frame on the either side of the specimen, was $1000 \mathrm{kN}$.

Uniaxial and multi-axial extensometers, linear variable displacement transducers and load cells were used for the test program. The component yielding and the failure of the specimens could be determined by extensometers, which be placed at the region of highest stress. The value of displacement and load at the loading point could be measured without delay after the setup of linear transducers and load cells.

The testing procedure was controlled by load in elastic phase and by displacement after getting into the plastic phase until failure occurred. The main test contents include: (1) The vertical load force of beam end, (2) The vertical displacement of beam end, (3) Strain of panel zone, (4) Rotation of panel zone, and (5) Failure process of joints.

\section{RESULTS AND DISCUSSION}

\subsection{Analysis of Rotation-Displacement Characteristics}

As shown in Fig. (7), displacement at the load-end of the beam is not completely proportional to the rotation of the panel zone $[10,11]$. Take end-plate connection for example, the relative rotation of the panel zone is caused by the bending of end-plate and column web, however interior joints under symmetrical loading could ignore the effect of column web in bending. The relative rotation of the panel zone $\left(s_{1}\right)$ and bending deflection of the beam $\left(s_{2}\right)$ contribute to the displacement of loading end in elastic phase, and the plastic hinge rotation of the beam $\left(s_{3}\right)$ should be considered in plastic phase. For seat angle with double web angles connection, web angles in tension, seat angle in bending and high strength bolts in shear contribute to the relative rotation of the panel zone. Moment-rotation relationship before and after the appearance of the plastic hinge on the beam are given by:

$$
\begin{aligned}
& s=\theta L+M L^{2} /(3 E I) \\
& s=\theta L+\theta^{\prime} L+M L^{2} /(3 E I)
\end{aligned}
$$

Where

$s$ - the displacement at the loading end of the beam

$\theta$ - the relative rotation of the panel zone

$\theta^{\prime}$ - the plastic hinge rotation of the beam

$M$ - the bending moment of the connection

$L-$ the distance between the loading application point and the face of the column web

$E$ - the elastic modulus of the beam

$I$ - the inertia moment of the beam

$M L^{2} /(3 E I)$ - the bending deflection of the beam

These four specimens showed very satisfactory behavior after the tests. Main experimental results are shown in Table 3 .

As shown in Table $\mathbf{3}$, the moment capacity and rotational stiffness of TS3 and TS4 are much higher than that of TS1 and TS2 respectively. It can be deduced that the stiffness of the minor-axis joints increased a lot when the effect of the concrete slab was taken into consideration, so the concrete slab played an important role in the mechanical performance of the minor-axis joints. In addition, the failure modes of the minor-axis composite joints were concrete cracking or reinforcing bars yielding, while the failure modes of the bare steel joints were steel components yielding.

\subsection{Tests on Bare Steel Joints Loaded along the Minor- axis}

\subsubsection{Test Results for TS1 and TS2}

The loads applied on both sides of the specimen were symmetrical and equal. As for TS1, this load mode was aimed at investigating the interaction between the flush endplate in bending and the high strength bolts in tension, eliminating the effect of column web, and for TS2, the

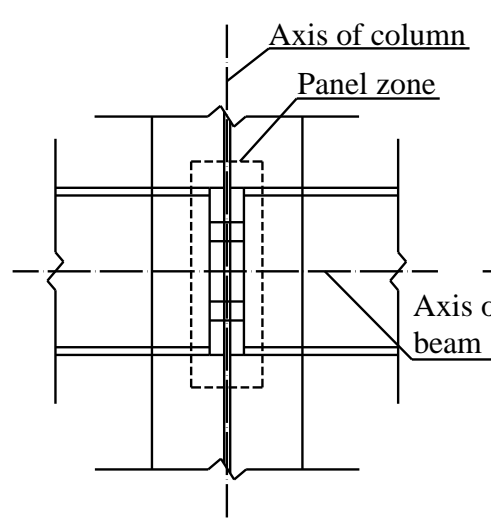

End-plate connection

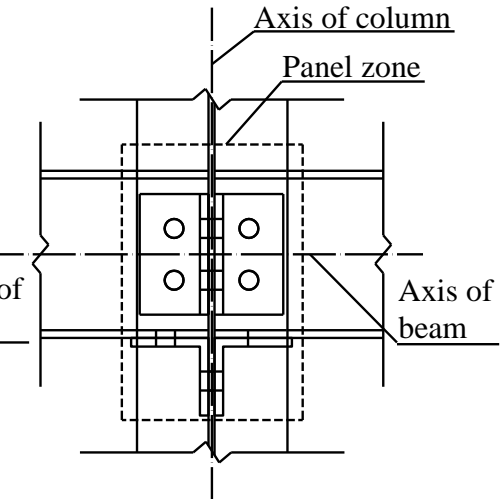

Seat angle with double web angles connection

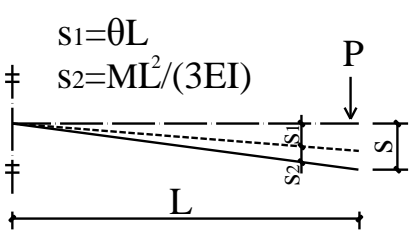

Elastic phase

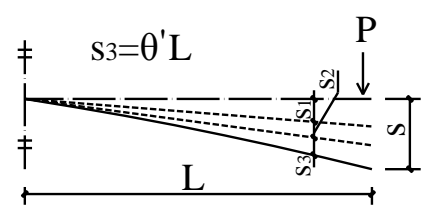

Plastic phase

Fig. (7). Moment-rotation characteristics for minor-axis connection. 
Table 3. Main experimental results of specimens.

\begin{tabular}{|c|c|c|c|c|c|c|c|}
\hline $\begin{array}{l}\text { Specimen } \\
\text { Number }\end{array}$ & $\begin{array}{l}\text { Loading } \\
\text { Mode }\end{array}$ & $\begin{array}{l}\text { Yield Moment } \\
\quad(\mathrm{kN} \cdot \mathrm{m})\end{array}$ & $\begin{array}{l}\text { Rotation with Yield } \\
\text { Moment(rad) }\end{array}$ & $\begin{array}{l}\text { Max Moment } \\
(\mathrm{kN} \cdot \mathrm{m})\end{array}$ & $\begin{array}{l}\text { Rotation with Max } \\
\text { Moment(rad) }\end{array}$ & $\begin{array}{c}\text { Initial Stiffness } \\
(\mathbf{k N} \cdot \mathbf{m} / \mathbf{r a d})\end{array}$ & Failure Mode \\
\hline TS1 & $\begin{array}{l}\text { Hogging } \\
\text { Moment }\end{array}$ & 34.092 & 0.006708 & 51.138 & 0.043598 & 8982 & $\begin{array}{l}\text { End-plate } \\
\text { Yielding }\end{array}$ \\
\hline TS2 & $\begin{array}{l}\text { Hogging } \\
\text { Moment }\end{array}$ & 13.258 & 0.01108 & 21.781 & 0.041081 & 1936.1 & $\begin{array}{l}\text { Web Angles } \\
\text { Yielding }\end{array}$ \\
\hline \multirow{2}{*}{ TS3 } & $\begin{array}{l}\text { Hogging } \\
\text { Moment }\end{array}$ & 78.246 & $6.0723 \mathrm{e}^{-5}$ & 109.158 & $2.4135 \mathrm{e}^{-5}$ & 30906.5 & \multirow{2}{*}{$\begin{array}{l}\text { Concrete } \\
\text { Cracking, }\end{array}$} \\
\hline & $\begin{array}{l}\text { Sagging } \\
\text { Moment }\end{array}$ & & & - & & 34852 & \\
\hline \multirow{2}{*}{ TS4 } & $\begin{array}{l}\text { Hogging } \\
\text { Moment }\end{array}$ & 79.8 & $8.9 e^{-5}$ & 107.35 & $45.6179 \mathrm{e}^{-5}$ & 9778 & \multirow{2}{*}{$\begin{array}{c}\text { Concrete } \\
\text { Cracking, } \\
\text { Reinforcing } \\
\text { Bars Yielding }\end{array}$} \\
\hline & $\begin{array}{l}\text { Sagging } \\
\text { Moment }\end{array}$ & & & & & 15934.25 & \\
\hline
\end{tabular}

interaction of web angles in tension, seat angle in bending and high strength bolts in shear could be investigated by this load mode.

Experimental results are represented by plotting the $M-\theta$ curves for each specimen in Fig. (8). Where $M$ is the bending moment acting on the connection and $\theta$ is calculated by Eq.(1) and (2).

The rotation on both sides of the specimen shows a high degree of consistency according to the initial $M-\theta$ curves plotted in Fig. (8). And the initial rotational stiffness could also be calculated by this initial curve. When some steel components reached their yield limit, leading the loading process into plastic phase, the loading curves would create fluctuations. On the one hand, it is because that the plastic deformation of the steel is random, which results in the different deformation on both loading ends. On the other hand, these two loading ends of the specimen produce certain unbalanced moment, because the coordinated loading is not quite precise. In order to eliminate the effects of the fluctuations, this paper integrated the experimental data and got the average value of moment and rotation on both sides

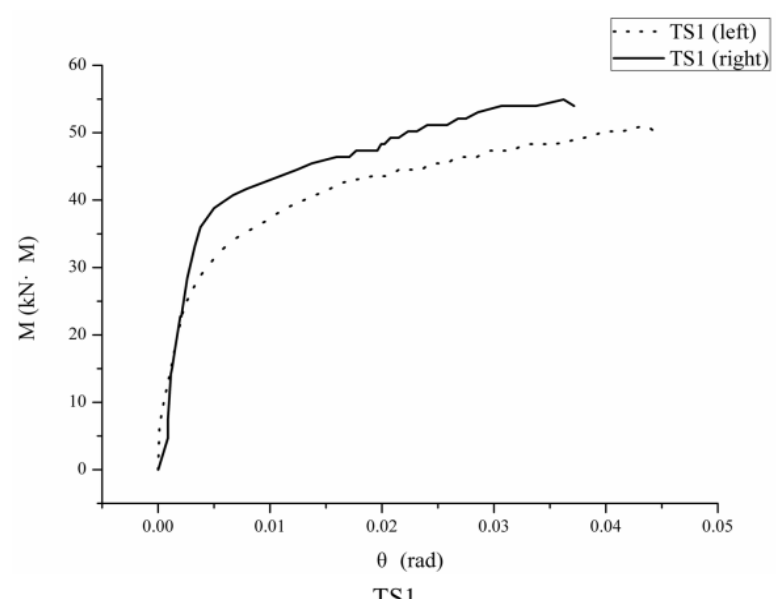

TS1 of the specimen. The revised moment-rotation curves are shown in Fig. (9).

\subsubsection{Discussion and Evaluation for TS1 and TS2}

The failure modes for TS1 and TS2 occurred in the steel components with large deformation. The deformation can't meet the requirements of the serviceability limit state according to reference [9]. It can be seen from Fig. (9) that these two minor-axis specimens showed obvious semi-rigid behavior and had a long plastic stage.

Fig. (10) shows a large out-of-plane deformation for TS1 occurred in the end-plate. The bending deformation of column web could be ignored due to the balance load applied on both sides of the interior joint. Obtained from the Eurocode 3 component method, two rows of bolts for TS1 were in a state of tension and the rotation center of the joint located at the junction of the beam flange in tension and the end-plate. The plastic deformation of TS1 mainly focused on the end-plate region adjacent to tensile flange, and the endplate region around the bolts also produced certain deformation due to the fixed action of the bolts. In the whole

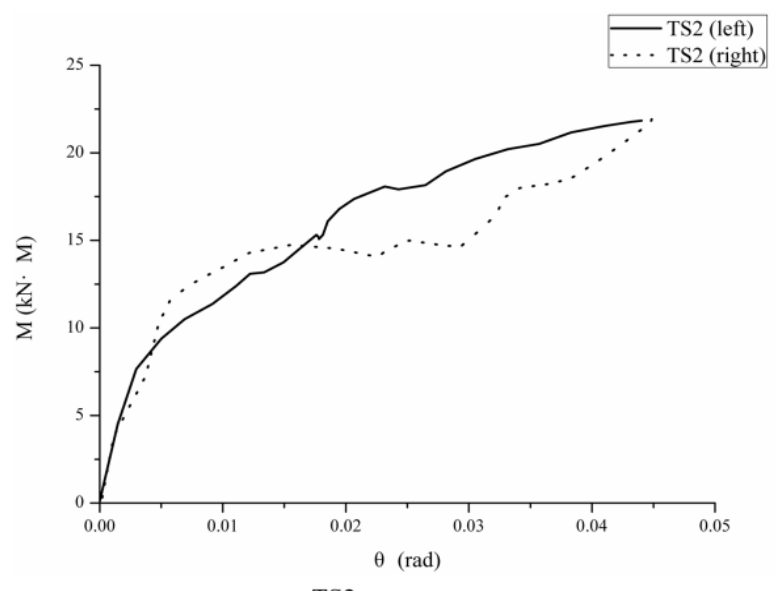

Fig. (8). Resulting moment-rotation behavior of TS1 and TS2. 


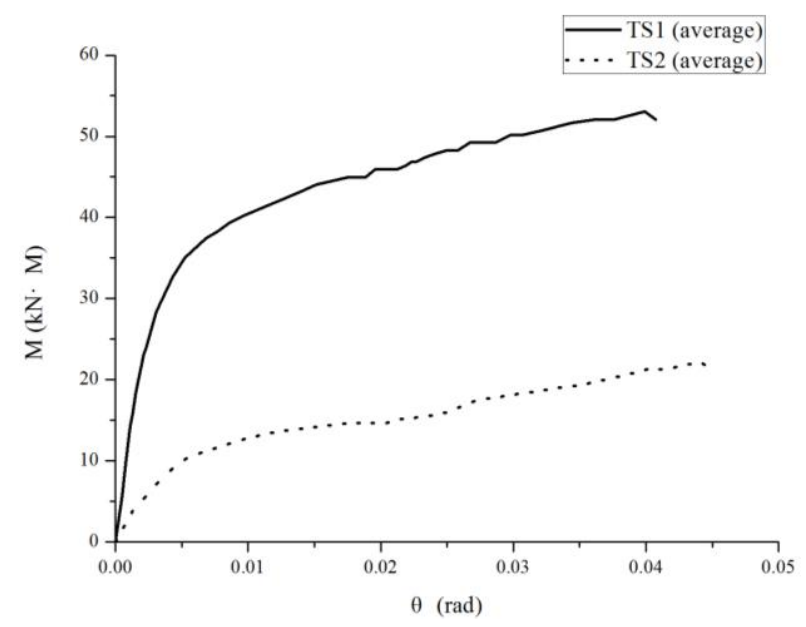

Fig. (9). Revised moment-rotation behavior of TS1 and TS2.

loading process, plastic hinge only occurred in the end-plate, and bolts didn't reach the tensile limit.

The main strengthening components of TS2 were angles. Two web angles produced large tensile deformation and bending deformation occurred in the seat angle. The bending deformation of column web could be also ignored because of the symmetrical loading. The double web angles were completely in a state of tension and the rotation center of the joint located at the corner of the seat angle. Bolts connecting the column web and angles were in tension. Bolts connecting the beam web and angles were in shear, which there would be loud sound during the loading process due to the effect of friction force. The plastic deformation of TS2 mainly concentrated on the angle region, and the bending deformation occurred on the bolts in shear, as shown in Fig. (11).

\subsection{Tests on Composite Joints Loaded along the Minor- axis}

\subsubsection{Test Results for TS3 and TS4}

The loading process of TS3 and TS4 was the same as that of TS1, however the mechanical behavior of the composite joints could be effected significantly by the reinforcing concrete slab and so the loading direction should be considered. This paper considered the action of sagging moment and hogging moment in elastic phase and got the

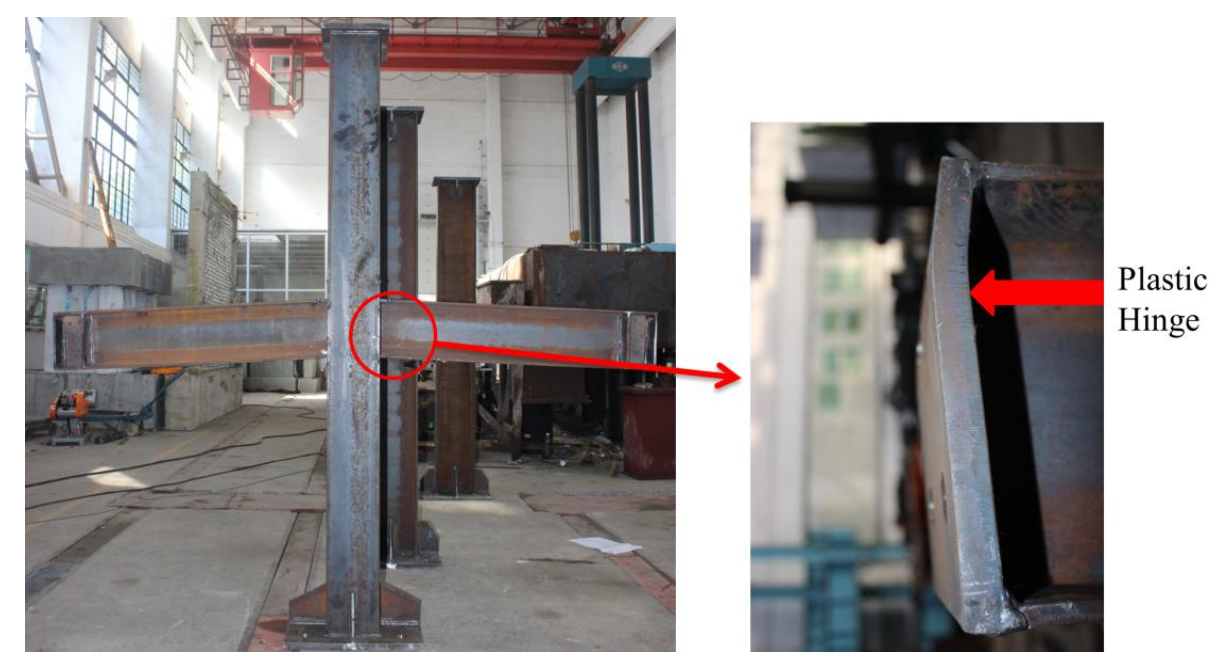

Fig. (10). Failure in test TS1.

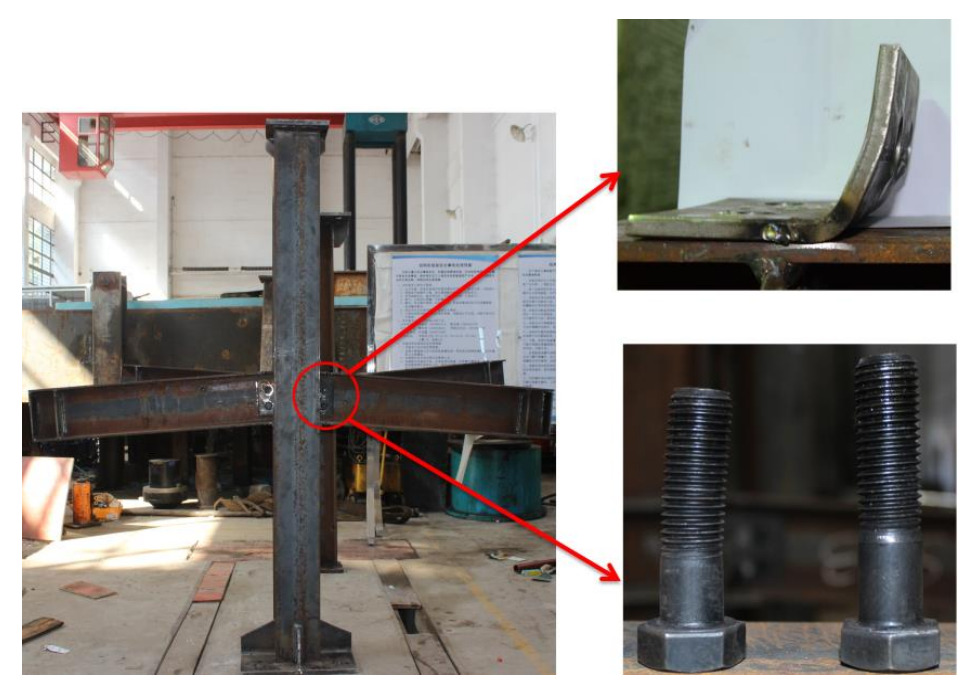

Fig. (11). Failure in test TS2. 
initial rotational stiffness of TS3 and TS4 in two directions, and loaded these two specimens up to failure under the hogging moment. It can be seen from Table $\mathbf{3}$ that the difference of the initial rotational stiffness in two directions is large. Fig. (12) shows the moment-rotation relationship under the effects of two different loading directions in elastic phase, the value of moment and rotation is averaged as same as Fig. (9). Even though the types of connections are different, TS3 and TS4 show similar mechanical characteristics, which the initial rotational stiffness under the sagging moment is bigger than that under the hogging moment. The reading of the extensometers positioned on the concrete slabs and the reinforcing bars clearly reflected that. When the specimen is under sagging moment, concrete slab is in compression and plays an important role in the improvement of the initial rotation stiffness. When the specimen is under hogging moment, the reinforcing bars in concrete slab are in tension and contribute to the increase of the stiffness.

\subsubsection{Discussion and Evaluation for TS3 and TS4}

The failure mode of composite joints is different from that of bare steel joints. Large cracking deformation occurred

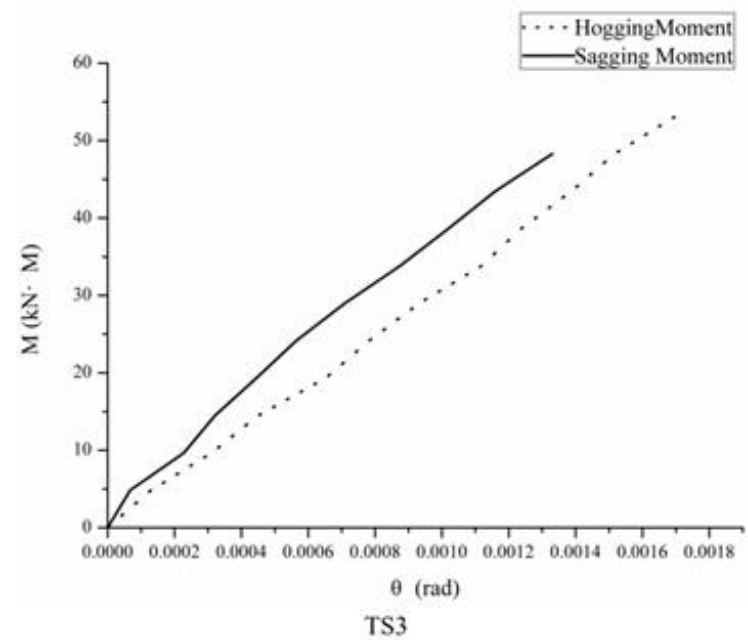

Fig. (12). Elastic moment-rotation behavior of TS3 and TS4.

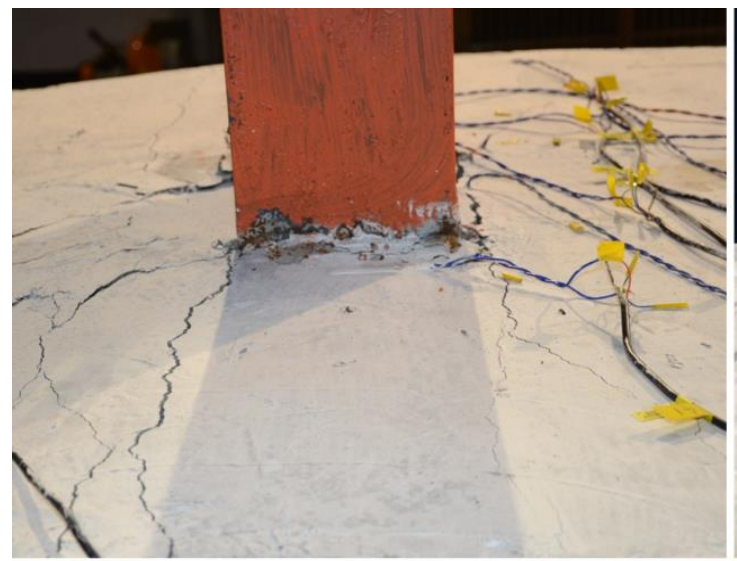

(a)TS3 in the concrete slabs which did not meet the requirement of the serviceability limit state according to reference [8].

When the sagging moment was applied, the end-plate bending effect was much less than the compressive action of the concrete. The rotation center of the minor-axis joints was in the center of the concrete slabs in compression, and two rows of bolts in the connection were in tension. Under hogging moment, the concrete in tension could be ignored and the reinforcing bars in slab contributed to the moment resistance of the joints. Moreover, the rotation center of the joint located at the junction of the beam flange in tension and the end-plate. With the increase of deformation in loading process, profiled steel sheet separated from the concrete slab. Due to stronger constraint of the steel connection, cracking developed from loading ends to mid-span. As shown in Fig. (13), concrete cracks of TS3 mainly concentrated around the column region and developed to all around, while cracks of TS4 in concrete slab developed along the slab span.

Concrete cracks developing in TS3 and TS4 are different. It is because the stiffness of bare steel part of TS3 is bigger than that of TS4, and the full shear connection is adopted between the slab and steel beam. Constraint stiffness of TS3 is larger, which resulted in the scatter of the cracks. While
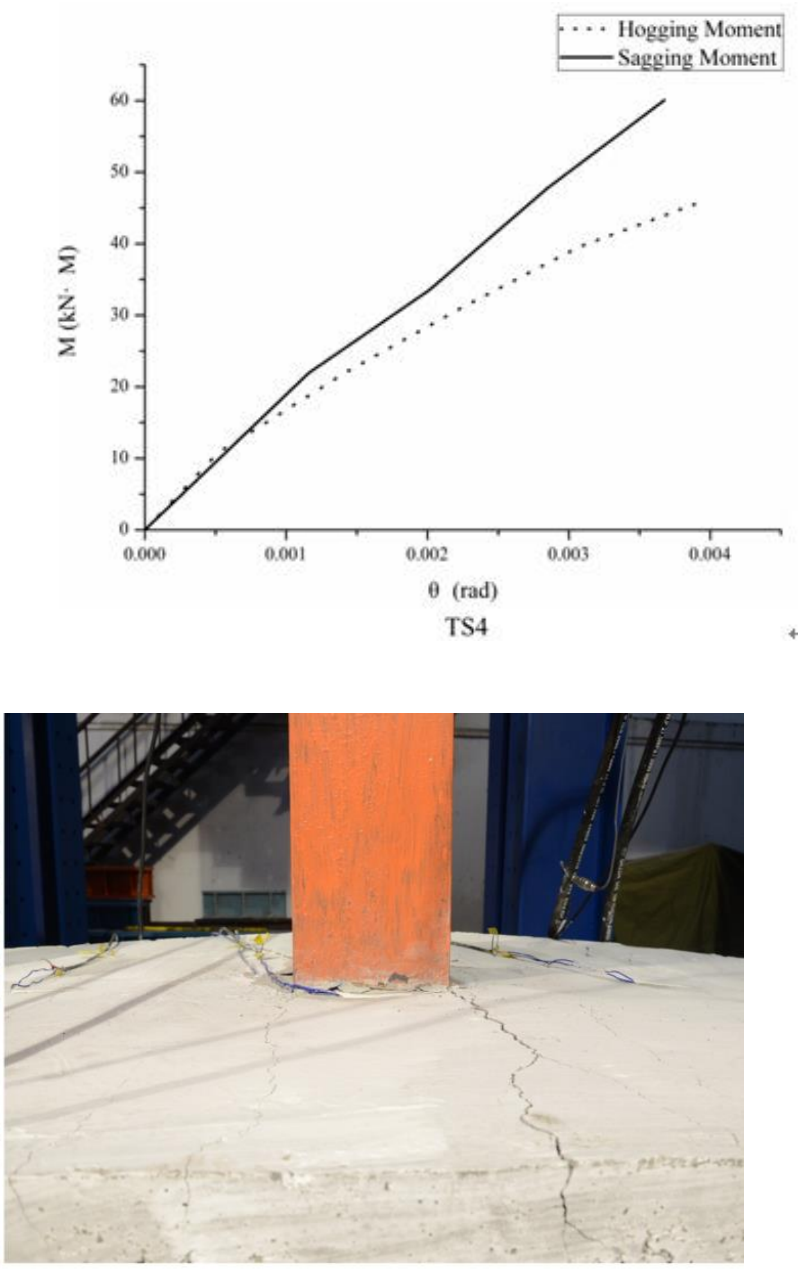

(b)TS4

Fig. (13). Failure in test TS3 and TS4. 
constraint stiffness of TS4 is weaker, crack development is uniform.

\section{CONCLUSIONS}

The behavior and the capacity of the four minor-axis connections were investigated by using monotonic tests. Main conclusions can be drawn as follows:

(1) The minor-axis joints with flush end-plate connections and seat angle with double web angles connections are all typical semi-rigid joints. The bearing capacity and the rotation ability of the joints cannot be ignored in the design.

(2) The minor-axis bare interior joints under monotonic symmetrical loading show good ductility.

(3) The mechanical property of the minor-axis composite joints is different from that of the minor-axis bare steel joints. Due to the composite effects of the concrete slab, sagging moment and hogging moment must be taken into consideration when the mechanical model is established using component method. In addition, the concrete slab increases the stiffness and bearing capacity of minor-axis joints and makes the mechanical performance of the joints more realistic.

(4) The failure mode of the composite joint is different from that of the bare steel joint. The plastic deformation of the bare steel joint mainly concentrates on the panel zone, while the plastic deformation of the composite joint mainly concentrates on the concrete slab or the reinforcing bars in the slab.

\section{CONFLICT OF INTEREST}

The authors confirm that this article has no conflicts of interest.

\section{ACKNOWLEDGEMENTS}

This study was supported by the National Nature Science Foundation of China (No.51178192, No. 51378219), State Key Lab of Subtropical Building Science, South China University of Technology (No.2012ZA05).

\section{REFERENCES}

[1] L. S. da Silva, R. D. Simoes, and P. J. S. Cruz, "Experimental behaviour of end-plate beam-to-column composite joints under monotonical loading", Eng. Struct., vol. 23, pp. 1383-1409, May 2001.

[2] B. Gil, and E. Bayo, "An alternative design for internal and external semi-rigid composite joins. Part I: experimental research", Eng. Struct., vol. 30, pp. 218-231, Mar. 2007.

[3] B. Gil, and E. Bayo, "An alternative design for internal and external semi-rigid composite joints. Part II: Finite element modelling and analytical study", Eng. Struct., vol. 30, pp. 232-246, Mar. 2007

[4] L. R. O. de Lima, S. A. L. de Andrade, P. C. G. da S. Vellasco, and L. S. da Silva, "Experimental and mechanical model for predicting the behavior of minor axis beam-to-column semi-rigid joints", Int. J. Mech. Sci., vol. 44, pp. 1047-1065, 2002.

[5] L. R. O. de Lima, J. L. de F. Freire, P. C. G. da S. Vellasco, S. A L. de Andrade, and J. G. S. da Silva, "Structural assessment of minor axis steel joints using photoelasticity and finite elements", $J$. Construct. Steel Res., vol. 65, pp. 466-478, Jan. 2008.

[6] CEN. Eurocode 3: Design of steel structures--Part 1.8: Design of joints, EN 1993-1, Brussels, Belgium, 2005.

[7] CEN. Eurocode 4: Design of composite steel and concrete structure--Part 1.1: General rules and rules for buildings, EN 19942, Brussels, Belgium, 2004.

[8] GB 50010-2010, Code for Design of Concrete Structures, China Architecture \& Building Press, Beijing, 2010.(in Chinese)

[9] GB 50017-2003, Code for Design of Steel Structures, China Planning Press, Beijing, 2003.(in Chinese)

[10] W. Zhan, and W. Tao, "Experiment and finite element analysis for the end plate minor axis connection of semi-rigid steel frames", China Civil Eng. J., vol. 45, pp. 83-89, Aug. 2012.

[11] W. Tao, W. Zhan, and W. J. Qi, "Experimental study and finite element analysis of hysteretic behavior of end-plate connection semi-rigid space steel frames", Open Civil Eng. J., vol. 7, pp. 6876, Apr. 2013.

Received: September 17, 2014

Revised: December 17, 2014

Accepted: December 23, 2014

(C) Chen et al.; Licensee Bentham Open.

This is an open access article licensed under the terms of the Creative Commons Attribution Non-Commercial License (http://creativecommons.org/licenses/ by-nc/3.0/) which permits unrestricted, non-commercial use, distribution and reproduction in any medium, provided the work is properly cited. 